Fixed Point Theory, 19(2018), No. 2, 503-514

DOI: $10.24193 /$ fpt-ro.2018.2.40

http://www.math.ubbcluj.ro/ ${ }_{\text {nodeacj/sfptcj.html }}$

\title{
EXISTENCE OF SOLUTIONS FOR A CLASS OF FUNCTIONAL DIFFERENTIAL INCLUSIONS WITH "MAXIMA"
}

\author{
AURELIAN CERNEA \\ Faculty of Mathematics and Computer Science, University of Bucharest, \\ Academiei 14, 010014 Bucharest, Romania, \\ Academy of Romanian Scientists, \\ Splaiul Independenței 54, 050094 Bucharest, Romania \\ E-mail: acernea@fmi.unibuc.ro
}

\begin{abstract}
We study a boundary value problem associated to a second-order differential inclusion with "maxima". Several existence results are obtained by using suitable fixed point theorems when the right hand side has convex or non convex values.
\end{abstract}

Key Words and Phrases: Differential inclusion, selection, fixed point.

2010 Mathematics Subject Classification: 34A60, 34K10, 47H10.

\section{REFERENCES}

[1] D.D. Bainov, S. Hristova, Differential equations with maxima, Chapman and Hall/CRC, Boca Raton, 2011.

[2] A. Bressan, G. Colombo, Extensions and selections of maps with decomposable values, Studia Math., 90(1988), 69-86.

[3] C. Castaing, M. Valadier, Convex Analysis and Measurable Multifunctions, Springer, Berlin, 1977.

[4] H. Covitz, S.B. Nadler jr., Multivalued contraction mapping in generalized metric spaces, Israel J. Math., 8(1970), 5-11.

[5] M. Frignon, A. Granas, Théorèmes d'existence pour les inclusions différentielles sans convexité, C.R. Acad. Sci. Paris, Ser. I, 310(1990), 819-822.

[6] L. Georgiev, V.G. Angelov, On the existence and uniqueness of solutions for maximum equations, Glasnik Mat., 37(2002), 275-281.

[7] P. Gonzalez, M. Pinto, Convergent solutions of certain nonlinear differential equations with maxima, Math. Comput. Modelling, 45(2007), 1-10.

[8] A. Ivanov, E. Liz, S. Trofimchuk, Halanay inequality, Yorke 3/2 stability criteria and differential equations with maxima, Tohoku Math. J., 54(2002), 277-295.

[9] A. Lasota, Z. Opial, An application of the Kakutani-Ky-Fan theorem in the theory of ordinary differential equations, Bull. Acad. Polon. Sci. Math., Astronom. Physiques, 13(1965), 781-786.

[10] M. Malgorzata, G. Zhang, On unstable neutral difference equations with "maxima", Math. Slovaca, 56(2006), 451-463.

[11] D. O'Regan, Fixed point theory for closed multifunctions, Arch. Math. (Brno), 34(1998), 191197. 
[12] D. Otrocol, Systems of functional differential equations with maxima, of mixed type, Electronic J. Qual. Theory Differ. Equations, 2014(2014), no. 5, 1-9.

[13] D. Otrocol, I.A. Rus, Functional-differential equations with "maxima" via weakly Picard operator theory, Bull. Math. Soc. Sci. Math. Romania, 51(99)(2008), 253-261.

[14] D. Otrocol, I.A. Rus, Functional-differential equations with "maxima", of mixed type, Fixed Point Theory, 9(2008), 207-220.

[15] E.P. Popov, Automatic regulation and control, Nauka, Moskow, 1966 (in Russian).

[16] E. Stepanov, On solvability of some boundary value problems for differential equations with "maxima", Topol. Meth. Nonlin. Anal., 8(1996), 315-326.

Received: January 6, 2016; Accepted: April 14, 2016. 
